\author{
Łukasz Białkowski \\ Faculty of Art \\ The Pedagogical University of Cracow \\ Ibialkowski@up.krakow.pl
}

\title{
FROM ARTIST GONE UNDERGROUND TO OCCUPATIONAL REALISM. REMARKS ON ARTISTIC STRATEGIES BASED ON INVISIBILITY
}

\begin{abstract}
The article discusses the problem of invisibility in the context of visual arts. An outline of six types of artistic activities in which invisibility or the artist's disappearance plays a pivotal role is followed by a presentation of artistic practices called a strategy of mimicry. The latter consists in enacting by artists such jobs as a waitress, a cleaner or a sales representative and regarding these occupations as artistic activities. The tendencies are discussed based on Stephen Wright's conception of 'escapology' and Julia Bryan Wilson' 'occupational realism'. The article raises questions concerning ethical repercussion of these activities and the fluid status of their identity, which, according to the author, paradoxically leads to evoking the Romantic figure of the artist.
\end{abstract}

Keywords: invisibility, escapology, occupational realism, underground

In 1964, Calvin Tomkins conducted one of his many interviews with Marcel Duchamp. During the conversation, he asked the French artist the following question: "How do you think a young artist could attempt to break out of the present situation, as you broke out of the situation before the First World War?" Duchamp's reply has now become a catchphrase: "I think the great man of tomorrow in the way of art cannot be seen, should not be seen, and should go underground. He may be recognized after his death if he has any luck, but he may not be recognized at all. Going underground means not having to deal in money terms with society." ${ }^{1}$ After the dramatic, but not entirely

1 C. Tomkins, Marcel Duchamp. The Afternoon Interviews, Badlands Unlimited, New York, 2013, p. 28. 
comprehensible pronouncement, he added: "the underground business is very interesting because an artist may be a real genius today, but if he is spoiled or contaminated by the sea of money around him, his genius will completely melt and become zero."2

In mid-1960s, the heyday of American economy and art market, his words might have been read as yet another bon mot by the ageing French dandy, who had turned understatements and secrets into his artistic strategy. Meanwhile, carping about the art market did not prevent him and many others from gaining a comfortable position from selling artworks. Although Duchamp's words are nowadays quoted in reference to graffiti culture, urban activism, creating alternative models of the art world's operation and other activities ignoring official institutions and the market, the fact that the context of Duchamps' declaration was thoroughly Romantic and conservative is overlooked. His aim was, after all, to salvage the genius. Duchamp, unlike numerous contemporary 'underground artists', did not say a word about the necessity to reformulate the figure of the artists, redistribution of economic and symbolic capital, creation of alternative system of economic exchange within art world and other issues, which today are set pieces in the socially engaged artists' repertoire of tasks. On the contrary, the artist was content to conclude in the interview that "the artist attained the same status as an attorney or a physician. Some fifty years ago, we had been pariahs." ${ }^{3}$ In this perspective, the recent pariah's going underground becomes another eccentric gesture: a nouveau riche dissipation of symbolic capital artists fifty year ago did not have. The fact of the matter, however, is that a precise meaning of 'going underground' remains unclear: where and how the artist can be found; how they are to operate in such an underground; how they are to make a living; what rules of the underground are; why they would be freer from market mechanisms there; and, last but not least, why the artist ought to eschew these mechanisms, rather than opposing and problematizing them.

The text is, in a sense, an attempt to delineate various possible interpretations of what going underground might be. It is interpreted as a spectrum of various strategies that emphasize an invisibility of the artist. First, I will outline six types of activities that entail withdrawing from official artistic circulation, understood as the gallery and museum space. Next, I will scrutinize motivations and goals behind some of these activities. I will concentrate primarily on a model of invisibility I define as 'a mimicry model', which appears in Stephen Wright's conception of 'escapology' and Julia Bryan Wilson's 'occupational realism'.

2 Ibid.

3 Ibid, p. 25. 


\section{Modes of invisibility}

Invisibility seems to belong to the visual arts and objects produced within their framework by definition; the question remains, however, if it also belongs by definition to the figure of the artist. Approaches exhibited by 'underground artists' I would like to characterize here most often stem from the belief that such a correlation need not to occur, is undesirable or even aberrant. Regardless of which ideological premises lie behind such an appraisal of visibility, were we to look at the category from a historical perspective, it would become evident that the artist's visibility - understood very broadly: from the eighteenth-century formation of the concept of copyright, through fetishization of the signature, recognizability as a condition for an art career, to celebritism - has been nothing more than a sort of 'occupational accident' that befell Western European culture. There were entire eras (such as European Middle Ages) and cultural formations (e.g. ancient Rome ${ }^{4}$ or India ${ }^{5}$ ), in which the authorial figure in the field of visual arts was treated quite nonchalantly, consigning them to anonymity or even non-existence. Irrespective of where we may look for causes of such state of affairs, Western European notion of the artist with all its mechanics of generating his or her visibility is one option in a whole array of cultural patterns.

As for artists' motivations or worldviews directing them towards the decision to disappear or 'go underground', at least six models of such activities seem to be discernible. ${ }^{6}$ First of those, apparently the most trivial, albeit often related to a mystery or a personal secret, is the model the standard example of which (to draw on a highly distinct character from beyond the domain of visual arts) was Arthur Rimbaud. It could be defined as the model of repletion or exhaustion. Here, we are dealing with a situation where the author, having achieved position and recognition in the art field, decides to forego art-making and dedicates themselves to an entirely different activity. In the following model, a disappearance or a lack of visibility is approached as a kind of position or a gesture towards the world of art. Here, we encounter a series of artists, from Arthur Cravan, through Marcel Duchamp and Lee Lozano, to Hito Steyrl. In this context, it seems not to matter whether the absence is a mere posturing

4 See: E. D'Ambra, Art and Identity in the Roman World. Weidenfeld \& Nicolson, London 1998.

5 See: S. Kramrish, The Art of India. Traditions of Indian Sculpture, Painting and Architecture, Phaidon, London 1955.

6 The 'typology' of invisibility here outlined makes no claim to completeness, while being based on activities hitherto identified by art critics and historians. Models proposed here are mutually inter-penetrable, creating 'hybrids', and due to their mere modularity, they are not always capable of encompassing special cases. 
adopted by an artist, or an actual severing of all relationships with the world of art, while directing attention towards the category of absence, which is supposed to become a celebration of lack, remains essential. An imperceptibility or an invisibility can serve not so much a function of a sign made towards the art world as being an aesthetic or artistic device. Then, it forms an element of the creative process, reinforcing a message of an activity, securing its added value, as happens in the case of activities by, e.g., Sophie Calle, Goran Trubljak or Jiři Kovanda. The fourth model rests on a series of strategies which are meant to guarantee an artist's anonymity due to a whole array of reasons: from political to psychological. This does not mean that the author remains completely anonymous. Their identity may be known to a select group of collaborators, while they decide to function in public space under a pseudonym or as part of a group; hence, the breadth of the model encompasses cases as varied as Banksy and Guerilla Girls. We should not forget to supplement the enumeration with artistic activities which, by means of disappearance or visibility avoidance, strive to elaborate alternative models of social relations: roles of the viewer, the artist and institutions of a politicaleconomic system in which art is operating, and by reformulating rules of art - the section of social life that the field of art is - they strive to create an alternative space for the functioning of social relations. The final model of disappearing, being, in a sense, a derivate of the one previously described, is a model in which disappearance can be likened to mimicry. As I have stated above, it is the model on which I would like to concentrate in this text.

\section{Political stakes of disappearing}

However, before I proceed to describing the aforementioned concepts of 'escapology' and 'occupational realism', I would like to briefly discuss the political aspect of disappearing related to attempts at developing alternative models of the art world. While foundational principles of the model are well-known to those concerned with the subject, it seems their delineation will allow for a clearer resonance of the concepts of 'escapology' and 'occupational realism'. Numerous socially engaged artists decide not to produce objects as works of art. They want the commodity that implicates the artist and the viewer in behaviors conforming to rules of the market and all their social consequences to disappear. ${ }^{7}$ What, then, is the role the author's disappearance plays in this context, and how could it be understood?

7 A standard expression of the type of approach is Dick Higgins' notion of intermedia, expressing the view that a rigid division into artistic domains is a resultant of the same logic that generates class divisions ("The idea that a painting is made of paint on canvas or that a sculpture should not be painted seems characteristic of the kind of social thought - categorizing and dividing society into nobility with its various subdivisions, untitled gentry, 
As a strategy for contesting market mechanisms, disappearing often stems from a belief that the art world, reproducing mechanisms of the capitalist economy, forces artists to compete and distinguish themselves over others, for the art world to operate more effectively on the market. In its 'soft' version, disappearing can, in fact, be identified with Duchamp's approach described above, which he dubbed 'going underground'. Its 'softness' consists in a desire to eschew rules of the market in a way that does not entail altering the idea of what an artist, with his/her Romantic attributes, is, including: the autonomy of the creative gesture, the need for expression, individualism, etc. In this case, disappearance is unrelated to an attempt at generating another model of the art world. In its 'hard' version, however, it determines the postulate of creating an alternative circulation to private galleries and exhibiting institutions. The disappearance from the mainstream exhibition space occurs in favor of a space that might also have a global reach, just as the capitalist economy is global, but would be based - against the regime of celebritism and competition for visibility - on different rules of exchange and distribution of economic and symbolic capital.

As for the figure of the author, a frequent translation of emphasis from individual productivity to collective productivity is performed here. In other words, where a measure of efficiency in the capitalist perspective is an individual success and a defeat of competition on grounds of available resources, a basic expression of contesting market rules becomes a redistribution of intellectual and material property onto a number of subjects. And if, according to Marx, the aim of the Communist revolution was an abolishment of class society, equally, the effect of collectivization of artistic activity - at least according to its standard model - is a flattening of social structure of actors operating in a parallel artistic circulation. In this sense, a disappearance of authorship takes place due to an inter-exchangeability of roles of the viewer and the artist as well as due to an even distribution of benefits and risks of performing artistic activities between all participants of such an alternative system. This type of attitude can be considered a model point of departure for the so-called 'participatory art'. Nevertheless, it has been repeatedly mediated by theoretical frameworks that are often vastly different from each other and place their emphases differently. At times, they underscore the collective aspect of artistic work, at others, the

artisans, serfs and landless workers - which we call the feudal conception of the Great Chain of Being.", D. Higgins, Intermedia, "The Something Else Newsletter", vol. 1, No. 1, February 1996, p. 1). Higgins believes that connecting media and shifting emphasis from the spatial to the temporal dimension of artistic activities, or a liquification of its structure, could allow for going beyond the traditional, bourgeois conception of the artwork as a product governed by rules of the market (ibid., p. 3). 
need for performative activities to replace a production of objects; sometimes, they highlight the potential of art as an instrument for recovering an immediacy of human relations, at others, they lean towards institutional critique: from Josef Beuys' 'social sculpture' to the notion of relational aesthetics. ${ }^{8}$

An array of typical arguments against such practices and theories has also developed, aiming to undermine meaning, potential or even honesty of strategies relying on a production of an alternative circulation. Where their defining point is collectiveness, questions are raised concerning the ineradicable role of the leader as well as the possibility of evenly distributing the prestige related to realization of artistic activities. When they invoke the autonomy of artistic activities as an 'alternative assembly line', doubts arise whether the purported autonomy of art, ostensibly allowing for a transcendence of the neoliberal economic context, might not be an effect of wishful thinking, and the art world with its 'autonomy' always remains entangled in an exchange with other spheres of life. Whenever performatics and effectiveness are stressed as basic elements of such a parallel circulation, charges are waged about the fact that even ephemeral activities can be transformed into market commodities by means of documentation or other traces they leave behind. Practically every proposal put forward from this field faces valid charges, multiplied in a thousand publications. ${ }^{9}$

\section{Mimicry}

Stephen Wright's 'escapology' and Julia Bryan Wilson's 'occupational realism' can be perceived as a peculiar reply to those charges. The CanadianFrench theorist constructs a conception which, on the one hand, is founded on a critique, typical to post-Marxist and post-Structuralist art theory, of such notions as: autonomy of art, disinterestedness of aesthetic experience, originality, or individual authorship. Wright observes reproductions of neo-liberal logic on many levels of art world's operation and, following in footsteps of Walter Benjamin and Guy Debord, builds a theory which aims to demonstrate possibilities of escape from the spectacle, and which in lieu of art watching, introduces its use.

8

In the Polish context, the most pronounced theory to have been proposed in recent years is Kuba Szreder's $A B C$ projektoriatu [An ABC of the Projectoriat], a skilful conglomerate of intuitions expressed by Gregory Sholette, Paslac Gielen and Stephen Wright, among others. The Polish sociologist and activist's book outlines a strategy for erecting 'pata-institutions', designed to operate in parallel to the official system of art, which reproduces mechanisms of the neo-liberal economy. The position of the alternative systems would be a gift economy, and its purpose - a far more just distribution of symbolic capital among subjects involved in production of artistic activities (See: K. Szreder, ABC projektariatu, Bęc Zmiana, Warszawa 2016, pp. 129-221).

9 See: C. Bishop, Artificial Hells, Verso, London-New York 2012, pp. 8-19. 
Escapology - one of the key concepts for the perspective he delineated is defined by Wright as "the theory and practice of suspending the operations of all [...] mechanisms of capture." ${ }^{10}$ An escape from the territory of art could consist in stepping into a terrain where all factors 'guaranteeing' autonomy of art become suspended, and art becomes action. However, in connection with the fact that the very rules generating an autonomy of art or of artistic activities are an elusive thing, and that the autonomy merely has an ideational nature, going beyond it can also only be arbitrary. It does not mean that the escape is itself impossible, but for it to be effective, it must become a conception of a step further, an overtaking of the 'autonomizing' thought. As Wright argues: "Escapology is the science of the kind of everyday elusiveness, leakage and doing-otherwise that can really only be described as 'escape' once power structures shift to capture its movement." 11 The escape is not, therefore, a one-off act, but a continuous process, veering between traps set for the escaper and evading them. "Escapology [...] is less the study and implementation of sets of tactics or strategies for avoiding capture, than the acknowledgement of a simple, concrete fact: escape happens." ${ }^{2}$ In Wright's theory, it is insufficient to contest the art world as an enduring set of practices, rules and institutions, which can be opposed by creating counter-practices, counter-rules and counter-institutions. Such a move will have always remained nad've and every gesture will have been transformed into an affirmation of its opposite. Furthermore, a creation of counter-activities remains in the realm of the spectacle, just like the art world, which it is supposed to oppose. Like the aforementioned Walter Benjamin and Guy Debord, who linked the presence of an art-work in public space to the risk of its spectacularization, Wright concedes that the stake of invisibility is an escape from the arbitrary, spectacular world of art - into the true world of life. He sees the possibility in shifting the emphasis from watching towards making a use of the artwork.

The artwork usership, in his understanding, is quite peculiar and consists in employing 1:1 scale. As he claims, the etymology of the English verb, escape, can be traced back to the Latin ex-capere (ex - beyond; capere - arrest/capture) but the verb is usually derived from the Vulgar Latin, ex cappa, "in reference not to capture at all but to a 'cape' or cloak which remains behind even as the living body which it had clad has slipped away." 13 The art world in his conception is such a cape that always desires to encompass the naked body, giving it

10 S. Wright, Toward a Lexicon of Usership, Museum of Arte Útil Van Abbemuseum, Eindhoven 2014, p. 23.

11 Ibid, p. 24.

12 Ibid, p. 23.

13 Ibid, p. 24. 
protection (or else, autonomy), which, nevertheless, will always remain arbitrary. Like a map that merely mirrors shapes of a territory. A hope for an escape to begin, according to Wright, is incited at the point when a fugitive takes notice of "the ontological discontinuity between map and land - and by extension, between art and whatever life form it permeates - disappears as soon as the territory is made to function on the 1:1 scale as its own self-styled cartograph."14 In other words, a chance to effectively escape the ideational autonomy of the world of art is a play between the real and the delusional.

Intricacies of those metaphors may become more tangible when we realize that one of the artists who, for Wright, is a model embodiment of an escapological practice is Raivo Puusemp. The American artist of Estonian descent was associated with the circle of New York conceptualists. His most famous project concerns the town of Rosendale in New York State, but prior to it, in a series of other activities, e.g. operating as a tacit, absent inspirator, the artist worked in 'planting ideas'. As he recalls: "I cued other artists with ideas, either by suggestion, or by dropping them in conversation, and if my idea was picked up, exhibited or published, I considered my 'work' to have been made." ${ }^{15}$ In his best-known project, however, he went much further: "In 1975, he employed ... a conceptual technique in a political activity and became a mayor of a small town of Rosendale in New York State, which was struggling with numerous financial and municipal problems. Within a year, he managed to convince its residents that the best solution to their problems would be a dissolution of the very town." ${ }^{16}$ Residents agreed to the artist-mayor's proposal, and the town was, in fact, dissolved and became a part of another urban body, of the same name. Puusemp is said to have moved to the Rockies, where he became a ski dealer.

Puusemp's project, a standard escapologist realization for Wright, also partially belongs among a series of practices that Julia Bryan Wilson describes as 'occupational realism'. The phrase appeared in the title of an article published in the magazine "TDR/The Drama Review" in 2012. ${ }^{17}$ There, the American critic presented practices in which "the realm of waged labor (undertaken to support oneself economically) and the realm of art (pursued, presumably, for reasons that might include financial gain, but that also exceed financialization and have aesthetic, personal, and/or political motivations) collapse, becoming indistinct or intentionally inverted. These are performances in which artists

14 Ibid, p. 4.

15 R. Puusemp, Umyślne oddziatywanie, transl. K. Szreder [in:] Prawda jest konkretna, transl. E. Majewska, K. Szreder, Bęc Zmiana, Warszawa 2018, p. 119 [back translation from the Polish].

16 Ibid.

17 J. Bryan Wilson, Occupational Realism, „TDR: The Drama Review”, vol. 56, Issue 4, Winter 2012, pp. 32-48. 
enact the normal, obligatory tasks of work under the highly flexible label of 'art'. Here, the job becomes the art and the art becomes the job." 18 The artists she discusses include, e.g.: Ben Kinmont, who has been conducting, since the late 1990s until this day, his project, 1998-ongoing. Ben Kinmont Bookseller, which consists in running a bookshop; ${ }^{19}$ the author also uses an example of Linda Mary Montano, who in 1973 produced her activity, Odd Jobs, performing "housework such as light hauling, cleaning cellars, interior painting, or gardening" 20 - which she approached, on the one hand, as an art project, and on the other, as a result of reconciling herself to the fact she had previously undertaken similar activities to support herself; a description is also found in Wilson's text of Bonnie Sherk's projects, who in 1974 produced her work, Short Order Cook, consisting in preparing hamburgers for clients of Andy's Donuts diner; subsequently, she also considered her waiting job as a long-term performance, entitled simply Waitress; ${ }^{21}$ among other, similar activities, we discover the piece, Training in Assertive Hospitality, by Daniel Bozhov, an artist of Bulgarian origin, who in 2000 worked in one of American supermarkets as a 'people greater';22 in turn, Sean Fletcher conceived of his sales representative occupation as artistic activity, a job he undertook, looking for a source of income after graduating from an art department: his project, Becoming a Life Insurance Salesman as a Work of Art, lasted from 1996 until 2002, when Fletcher's boss realized that the artists used an office as an exhibition opening venue on weekends. ${ }^{23}$

Julia Bryan Wilson lists numerous other projects of this sort. In her view, they are all connected by at least two characteristics. First, while ignoring the traditional museum or gallery space, these artists are not in any way interested in theatricality and, therefore, often conceal the artistic dimension of their activities from their collaborators. ${ }^{24}$ Rather than wanting to go 'on stage', they simply want to get on with activities arising from tasks with which they have been entrusted. Second, as the author points out, occupational realism differs from numerous socially engaged artistic activities, aiming to create alternative models of social relations and economic exchange, in its focus on 'normative economies', having no desire to reformulate, subvert or fight them in any way. It is a strategy of blending into economic conditions. ${ }^{25} \mathrm{~A}$ critical potential of these activities transpires, nonetheless, according to Julia Bryan Wilson, in

18 Ibid, p. 33.

19 Ibid, p. 32.

20 Ibid, p. 35.

21 Ibid, p. 36.

22 Ibid.

23 Ibid, p. 39.

24 Ibid, p. 37, 42.

25 Ibid. 
investigating conditions of precarity. As the American critic argues: "If occupational realism stems at least partially from jobs or work undertaken by artists because they 'have to' (though the issue of compulsion, need, and choice is unevenly applicable), this form of practice also raises questions about the potential strategic or operational value of precarity: its capacity to redefine social relations, aesthetic and affective production, and class structures." ${ }^{26}$ In addition, she claims that these activities can, in fact, be compared to the work of such artists as Courbet, who "were charged with showing the structures of social and political relations with all their ambiguities, including "class conflict and expropriation"”. ${ }^{27}$

From analyses she conducts with regards to particular artist's activities, it is, however, difficult to deduce concrete methods of investigation of the said precarity - an impression can only be had that the very position of the artists, who decided to go beyond the field of freelance occupation and enter the world of frequently low-paid, physical work, their performance of simple services, already presupposes a certain manifestation of their views about the capitalist regime of labor. This is supposed to take place by means of contrasting a freelance profession of the artist - with all its surrounding mythology grounded in notions of autonomy, unbridled expression and non-utilitarian dimension of artistic activities - with non-artistic occupations, deeply embedded in the logic of loss and gain, maximization of efficiency, supply and demand. By contrast, activities there described would point towards an existence of at least two problems. The first issue concerns a de facto similarity between the status of the artists and his work and the situation of contemporary precarious worker from beyond the art world. Here, the artist is a species of a precariat avant la lettre; ${ }^{28}$ a specificity of their profession - flexible working hours, moving from project to project, a lack of social insurance, and an uncertain future - has become a model of functioning for a number of people on the labor market, who came to be defined as the precariat. Another problem is the art world's brutality, pushing numerous young artists beyond its margins, having previously doomed them to ruthless competition with other artists, and in case of defeat, forcing them to find a 'regular job'. Remembering that numerous art-makers began to realize the activities described by Julia Bryan Wilson out of existential necessity - their ambitions and expectations as to their future could not have been realized - their projects can be regarded as a form of ostentatious question about human potential, opportunities for being successful, possibilities of upward

26 Ibid, p. 33.

27 Ibid, p. 43.

28 Ibid, p. 34. 
social mobility, life satisfaction and divergences between one's aspirations and actual reality under the condition of neo-liberal economy. ${ }^{29}$

\section{Symbolic capitalism and crypto-conservatism?}

The latest aspect relates to another problem both 'escapology' and the strategy of 'occupational realism' produce at the level of relationship between the artist and the viewer, bringing about a situation in which the relationship becomes asymmetrical, to the benefit of the author. Julia Bryan Wilson is, in fact, aware that the problem arises. In her article, she refers to established research from the 1960s, demonstrating that social stratification in the US was highly marked, and opportunities for social mobility and climbing up the class ladder were limited. ${ }^{30}$ Of course, one determinant of belonging to a particular social class is one's current occupation and resultant opportunities for wealth accumulation, life-style choice, education etc., bearing on a future of a particular individual and their offspring. As Julia Bryan Wilson observes: "The educational/vocational usage of 'occupational realism', which describes the necessity of being realistic about class limitations, demonstrates that 'job choice' is for some only illusory, and for others an obvious mark of privilege." 31

The claim can be interpreted ambivalently: on one hand, it suggests that also the artistic milieu is faced with the problem of illusoriness in choosing one's occupation, while on the other, the above-described projects were no less than the artists' choice. Most often, such a choice was unavailable to people in whose environment these projects were carried out. While the latter were, in a sense, doomed to perform often poorly paid jobs where no high qualifications are required, the artist who held an art school diploma occupied a privileged position. Although, in some cases the activities were occasioned by vital necessities, one's association with the artistic milieu, as well as connections and qualification determined that these projects extended over a relatively brief period, with an actual possibility glimmering in their background of a job change and leaving for a 'better world'. Thus, if we were to view them in the context of actual, long-term opportunities at the artists' disposal, it might transpire

29 Ibid, p. 40. Julian Bryan Wilson demonstrates the aspect, recalling the original use of the term, 'occupational realism', from the 1950s, when it had been used in education, behavioural psychology and sociology in reference to "the structuration of class mobility and the relative lack of ease of moving from one class position to another in the United States" (J. Bryan Wilson, ibid., p. 40).

30 J. Adelson, E. Douvan, The Adolescent Experience, John Wiley \& Sons Inc., New York J. Adelson, p. 78 (quoted in: J. Bryan Wilson, ibid., p. 40).

31 J. Bryan Wilson, ibid, p. 41. 
that their working as cheap labor was just as illusory as the unskilled workers', migrants' or marginalized social groups' actual opportunities for upward social mobility. The artist operated as aliens descended from other planets, transitorily assuming the role of the working class, only to vanish after a while. Thus, a classic reservation voiced about participatory activities surfaces here, which holds that artists only superficially infiltrate the milieu in which they work, and by defining their presence there as an artistic activity they achieve no more than aestheticization.

A questionability of Montano's, Bozhov's and others' position becomes particularly visible in the context of their disinclination to theatricality, declared - as the American critic maintains - by artists here described. The bookselling Kinmont says that a number of his clients probably guessed that he is also conducting an art project, but he prefers not to state it openly, as he fears his clients would treat him less seriously. ${ }^{32}$ We are dealing here with a peculiar case, where theatricality is supposed to be undermined, since the artists are 'really' doing their work, but a certain surplus - the artistic aspect - emerges at the same time, which is concealed from collaborators. Indeed, the peculiarity is pointed out by the author of "Occupational Realism": “(...) performances of this sort are not just 'acts' (though they are suffused with potential irony). At the same time, neither are they about unmediated access to anything that might be called 'real' - itself always fugitive, phantasmatic, and illusory." ${ }^{33}$ Also, the concealment of truth about the nature of those activities makes the relationship between these types of artists and their collaborator even more asymmetrical.

The artists are aware of the problem, which might also produce their own sense of discomfort. None of Rosendale residents knew that Pussemp treated his project as an artistic activity. The artist never confessed the fact to them, which was one condition - in the perspective Wright proposes - for a successful escape from the world of art. The mimicry had to be complete, to the extent that the 1:1 map of art sealed the town limits hermetically, and the two domains intermixed problematically to everyone involved; at least to the point when information about Pussemp's project became more widely known. As the artist admits: "I felt uneasy, doing something that savors of subterfuge and subversion. Analogously, the fact that I could not reveal my concept to people involved with Rosendale kept bugging me. It seemed to me like leading a double life and was, in a sense, dishonest; nonetheless, I still felt that revealing the goal of my activity would have precluded its achievement. ... Otherwise, it would have been impossible to introduce all the reforms I managed to implement during my time as the mayor, such as: drafting a new plan of the sewage system, re-

32 Ibid, p. 37.

33 Ibid, pp. 42-43. 
organizing the police department, improvement of various municipal services and, ultimately, formulating the proposal for town dissolution and convincing its resident to its application." 34

The asymmetricity of a relationship with witnesses and/(or) spectators to a project is especially visible in Puusemp's case, because of the power held by the American conceptualist. A scale of the disproportion is reduced in cases of Montano or Bozhov, for example; nonetheless, doubts still arise as to the subjective treatment of collaborators, whom the artists ascribed the role of unwitting figureheads in the spectacle performed.

It is questionable, however, whether intentions of an author who turns everyday activities into an art project are significant enough to define unaware participants as figureheads in a spectacle directed by somebody else. All in all, these activities are tantamount to the same kind of labor performed by everyone who undertakes them. What can be changed here by authorial intentions? Are they not merely an attempt at compensation of temporary or permanent life failure, and the artists, making the best of a bad bargain, imagine that their low-paid jobs amount to something more than what they seem to be in actual reality? Their projects, as a matter of fact, take place in their heads, and if this is the case, their collaborators are 'witnesses' to nothing but a fantasy project. The suspicion may hold a fair amount of truth, but if we want to undertake a serious analysis of these activities as artistic projects, the issue of authorial intention makes all the difference. Not only due to the fact that at least since The Fountain, it has been assumed that the author's declaration determines what a work of art is and what it is not (and if we accede to this in cases of objects exhibited in museums and galleries, why would we deny the same right to occupational realism?); but, most of all, due to the fact that declaring their intention of regarding their occupation as an artistic production, the discussed artists also assume a position towards other human beings, which becomes all the more questionable, when their intentions are concealed.

The problems of intention and hybrid - present and absent - theatricality lead us towards questions about ontology of such works of art and the author's role in preserving their substantiality. Which activities among those performed by artists were an artistic realization, and which were not? Did they encompass everything specific artists did during the period, sometimes lasting many years, during which they were conducting their project? Did the artistic dimension of their lives was limited only to working hours? Were moments spent on breaks with other colleagues, drinking coffee, smoking cigarettes, etc., part of a pro-

34 R. Puusemp, Umyślne oddziatywanie, transl. K. Szreder [in:] Prawda jest konkretna, transl. E. Majewska, K. Szreder, Bęc Zmiana, Warszawa 2018, p. 119 [back translation from the Polish]. 
ject? Every answer given may be true of false, and its only truth criterion will be the artist's intention. Intention lies at the basis of these projects - a declaration that a regular occupation will be a work of art - and, subsequently, intention becomes necessary at every instance, when any given thing, situation or person is or is not included within a scope of a realization.

However, if access to author's intention forms a criterion for defining what a work of art is and what it is not, a question arises whether we are not entering a traditional aesthetics, which demands author's presence and their intention at every instance when we want to interpret the work. Thus, it turns out that the author's intentions determine a substantiality of the art work and - seem to - evoke the category of a correct or a false interpretation. If the intuition is valid, then 'escapologist' or 'occupational realist' activities situate the addressee in such an interpretative position with regards to the work of art as that postulated by Wilhelm Dilthey ${ }^{35}$ or Benedetto Croce. ${ }^{36}$ There is nothing wrong with the position, in and of itself, but it lets us question whether the reference to authorial intention is in agreement with the socially engaged artists' egalitarian proposals. One stake in the artistic revolution of the 1960s - and activities described in this text, among many others, are, indeed, an aftermath of the revolution - was elaborating a formula for artistic production of maximum possible inclusivity, thereby equating the position of the artist and the viewer, or a departure from conceiving of the artist in Romantic terms. The question arises in this context whether artistic activities whose substantiality is founded on authorial intention might not be 'crypto-conservative', at the very least. They reinstate thinking about the work of art as a puzzle or a secret to be deciphered by discovering the author's thoughts, and distinguish the author's position at the expense of the addressee.

$* * *$

In Artificial Hells, Claire Bishop underscores the necessity for an improved lexicon of terms used today when speaking about participatory art. This refers especially to the role of the author and relationships they enter with participants of their activities. The lack of a sufficiently well-defined position of the author in cases of such activities often leads to the accusation that being an author is there "to glorify the artist's career and fame." ${ }^{37}$ Contrary to other fields of art, such as music, literature, fashion or the theatre, where numerous terms exist that describe co-authors' entering into mutual relationships (e.g.:

35 Cf. E. Paczkowska-Kagowska, Logos życia, Gdańsk 2000, p. 87.

36 Cf. Ł. Białkowski, Figury na biegunach. Narracje silnego i stabego podmiotu twórczego, Universitas, Kraków 2015, pp. 23-35.

37 C. Bishop, ibid., p. 8. 
editor, producer, stylist, photographer, sound coordinator) and each of those participants is appropriately marked and considered significant, ${ }^{38}$ visual arts still lack a language that would allow for various levels of co-authors' presence in a project's production. Hence, Bishop concludes: "The lack of an equivalent terminology in contemporary visual art has led to a reductive critical framework, underpinned by moral indignation." ${ }^{39}$

It is certainly the case that individual authorship still fares much better in the visual arts than in other fields, like music or film, where without team work and significant participation from various areas, it would have been impossible to achieve their goals. Nevertheless, it is difficult to demand of art critics and historians to gloss over doubts arising in instances of such activities as those described above, when they are building an asymmetric relationship between the artist and the viewer, and when this occurs against the egalitarian spirit of such activities. It does not alter the fact that - according to the author of this article - realizations produced in the context of 'escapology' or 'occupational realism' remain one of the most intriguing and interesting fields of activities, resigning both from a production of object as well as from presence in a museum or a gallery space. They are a radical consequence of the neo-avant-garde postulate - with its socio-political consequences - that art should melt into reality or, at least, a compelling variation on the postulate. Appraising such activities, it is worth remembering the standard aptly set out by Grant Kester in his Conversation Pieces. Community and Communication in Modern Art. He observed that that a dematerialisation of the artwork "must be understood not simply as a defensive tactic to forestall commodification but also as a positive or creative moment, marked by an increasing emphasis on art as a process of collaborative interaction". ${ }^{40}$

\section{BIBLIOGRAPHY}

Adelson J., Douvan E. (1966) The Adolescent Experience, New York: John Wiley \& Sons Inc.

Białkowski Ł. (2015) Figury na biegunach. Narracje silnego i stabego podmiotu twórczego. Universitas: Kraków, pp. 23-35.

Bishop C. (2012) Artificial Hells. London-New York: Verso.

Bryan Wilson J. (2012) Occupational Realism, „TDR: The Drama Review”, vol. 56, Issue 4, pp. 32-48.

38 Ibid., p. 9.

39 Ibid.

40 G. Kester, Conversation Pieces. Community and Communication In Modern Art, University of California, Berkeley-Los Angeles-London 2013, p. 53. 
D’Ambra E. (1998) Art and Identity in the Roman World. London: Weidenfeld \& Nicolson.

herbst s., Malzacher F. (eds.) (2014), Truth is Concrete. A Handbook for Artistic Strategies in Real Politics, Vienna: Sternberg Press

Higgins D. (1966), Intemedia, „The Something Else Newsletter”, vol. 1, no 1 February 1966, pp. 1-3.

Kester G. (2013) Conversation Pieces. Community and Communication In Modern Art. BerkeleyLos Angeles-London: University of California, 2013.

Kramrish S. (1955) The Art of India. Traditions of Indian Sculpture, Painting and Architecture. London: Phaidon.

Puusemp R. (2018) Umyślne oddziaływanie, [in:] F. Malzacher, S. Herbst, eds., Prawda jest konkretna, transl. E. Majewska, K. Szreder. Waszawa: Bęc Zmiana, p. 119.

Paczkowska-Łagowska E. (2000) Logos życia. Słowo/obraz terytoria: Gdańsk.

Szreder K. (2016) ABC projektariatu. Warszawa: Bęc Zmiana.

Tomkins C. (2013) Marcel Duchamp. The Afternoon Interviews. New York: Badlands Unlimited.

Wright S. (2014) Toward a Lexicon of Usership. Eindvohen: Museum of Arte Útil Van Abbemuseum.

\section{OD ARTYSTY PODZIEMNEGO DO REALIZMU OKUPACYJNEGO. UWAGI O STRATEGIACH ARTYSTYCZNYCH OPARTYCH NA NIEWIDZIALNOŚCI (streszczenie)}

Artykuł omawia zagadnienie niewidzialności w kontekście sztuk wizualnych. Po zarysowaniu sześciu typów działań artystycznych, w których niewidzialność lub zniknięcie artysty odgrywają kluczową rolę, przedstawione zostają praktyki artystyczne określone przez autora strategią mimikry. Polegają one na wykonywaniu przez artystów zawodów jak kelnerka, sprzątaczka czy przedstawiciel handlowy - i traktowaniu tych ich jako działań artystycznych. Tendencje te omówione zostają na przykładzie koncepcji „eskapologii” Stephena Wrighta oraz „realizmu okupacyjnego” Julii Bryan Wilson. W artykule zostają przestawione wątpliwości dotycząca etycznego wydźwięku tych działań oraz płynnego statusu ich tożsamości, który - zdaniem autora - prowadzi paradoksalnie do ewokowania romantycznej figury twórcy.

Słowa kluczowe: niewidzialność, eskapologia, okupacyjny realizm, podziemie 